\title{
Serological Detection of Citrus tristeza virus with Antibodies Developed to the Recombinant Coat Protein
}

\author{
M. M. Iracheta-Cárdenas, Instituto de Biotecnología, Facultad de Ciencias Biológicas, UANL, Pedro de Alba \\ s/n, Cd. Universitaria, San Nicolás de los Garza, Nuevo León 66450 México; P. Metheney, Central California \\ Tristeza Eradication Agency, and M. L. Polek, California Department of Food and Agriculture, Tulare 93274; \\ K. L. Manjunath and R. F. Lee, United States Department of Agriculture-Agricultural Research Service, National \\ Clonal Germplasm Repository for Citrus and Dates, Riverside, CA, 92507; and M. A. Rocha-Peña, INIFAP/UANL, \\ Unidad de Investigación en Biología Celular y Molecular, Apartado Postal 128-F, Cd. Universitaria, San Nicolás de \\ los Garza, Nuevo León 66450 México
}

\begin{abstract}
Iracheta-Cárdenas, M. M., Metheney, P., Polek, M. L., Manjunath, K. L., Lee, R. F., and RochaPeña, M. A. 2009. Serological detection of Citrus tristeza virus with antibodies developed to the recombinant coat protein. Plant Dis. 93:11-16.

Antibodies specific for the recombinant coat protein $(\mathrm{rCP})$ of the $p 25$ gene of Citrus tristeza virus (CTV) were developed in goats and rabbits and further evaluated as a complete kit for the detection of the virus using healthy and CTV-infected tissue. The combination of goat T1 used as primary (coating) and rabbit $\mathrm{C} 3$ as intermediate (detecting) $\mathrm{rCP}$ antibodies reacted efficiently, with optical density at $405 \mathrm{~nm}\left(\mathrm{OD}_{405}\right)$ values between 0.250 and 2.000 with samples from an international collection of diverse CTV isolates. The CTV isolates tested cause a broad spectrum of disease syndromes in different citrus hosts. The $\mathrm{OD}_{405}$ values for healthy tissue were less than 0.100. Likewise, the combination of goat $\mathrm{T} 1$ and rabbit $\mathrm{C} 3 \mathrm{rCP}$ antibodies gave consistent results for CTV-positive and -negative sample discrimination when directly compared with the Central California Tristeza Eradication Agency (CCTEA) antibodies used for large-scale CTV detection and a commercially available CTV serological detection kit. The combination of goat T1 and rabbit $\mathrm{C} 3 \mathrm{rCP}$ antibodies showed its suitability for large-scale indexing with samples collected in commercial groves as part of the CCTEA's regular monitoring program. The evaluation included 41,195 samples from 301 commercial groves from districts 1, 2, and 3. In total, 26 trees $(0.063 \%)$ were found to be $\mathrm{CTV}$ positive using the T1/C3 rCP antibody combination. Results of this research provide evidence that $\mathrm{rCP}$ antibodies can be efficiently used for both capturing and detecting CTV antigens in double-antibody sandwich indirect enzyme-linked immunosorbent assay.
\end{abstract}

Citrus tristeza virus (CTV) is distributed worldwide and causes the most economically important virus disease of citrus (33). CTV infects nearly all Citrus spp., cultivars, and intergeneric hybrids and some citrus relatives $(3,24)$; however, the most dramatic effect is the decline induced on plants grafted on sour orange (Citrus aurantium L.) rootstock. In addition, there are some strains of the virus that cause stempitting in the trunk and main branches on some oranges (C. sinensis (L.) Osb.), grapefruit $(C$. paradisi L.), and Tahiti lime $(C$. latifolia Tan.) regardless of the rootstocks, which frequently leads to severe tree deterioration and poor growth and yield (33). In the last 70 years, severe CTV epidemics

\footnotetext{
Corresponding author: M. A. Rocha-Peña E-mail: mrocha@fcb.uanl.mx, rocha.mario@inifap.gob.mx
}

Journal Series Number INIFAP`CIRNE•A-426.

Accepted for publication 30 August 2008.

doi:10.1094/PDIS-93-1-0011

(c) 2009 The American Phytopathological Society have occurred in different countries, with estimated tree losses of over 100 million citrus plants grafted onto sour orange rootstock $(5,9,33)$. Countries where CTV has caused extensive tree losses include Argentina, Australia, Brazil, Dominican Republic, Israel, Jamaica, South Africa, Spain, the United States, and Venezuela, among others $(5,9,14,22,33)$. Significant efforts are conducted every year in several countries to detect CTV-infected trees in order to prevent virus spread and future CTV epidemics, mostly in those citrus areas where sour orange still predominates as the main rootstock $(5,7,9,18,22,28,33,37,38)$. Since the enzyme-linked immunosorbent assay (ELISA) test (10) was implemented for CTV (2), several ELISA-based protocols have been developed $(4,8,15,34)$ and ELISA has become an indispensable tool for large-scale diagnosis of CTV worldwide for both research $(6,9,17,18$, $35,36,42)$ and disease-management purposes $(5,7,12,22,28,32,38)$. Antibody production for CTV diagnosis, either polyclonal $(4,16)$ (R. F. Lee, unpublished) or monoclonal $(6,27,40)$, has been accomplished in the past by using purified viri- ons as immunogens. Although some of these antibodies were produced and used for specific research purposes, others have been available as serological detection kits by several commercial suppliers for largescale diagnosis of CTV worldwide. In addition, several research groups have developed polyclonal antibodies to the recombinant p25 coat protein $(\mathrm{rCP})$ of CTV $(23,25,39)$. However, those rCP antibodies have shown inconsistent results as trapping antibodies under nondenaturing conditions $(1,25,26)$; hence, their use at a large scale have been limited only as intermediate antibodies in double-antibody sandwich indirect (DASI)-ELISA $(25,31)$ (M. L. Polek, unpublished). We have developed antibodies to the rCP of several CTV isolates from Mexico in goats and rabbits that have a remarkable suitability to perform as both primary (trapping) and intermediate (detecting) antibodies in DASI-ELISA tests (19). This work reports the evaluation of these $\mathrm{rCP}$ antibodies to detect the virus from a collection of CTV isolates from diverse geographic origins and compare their performance to a commercially available CTV detection kit and the established protocol from the Central California Tristeza Eradication Agency (CCTEA), and to determine their suitability for large-scale field indexing.

\section{MATERIALS AND METHODS}

Source of antibodies. Goat (T1) and rabbit (C3) antibodies were obtained against the rCP of CTV isolates MX08 and MX14 from Mexico, respectively (20). Untagged rCP from Escherichia coli transformed cells was purified using sodium dodecyl sulfate polyacrylamide gel electrophoresis (SDS-PAGE) and extensively dialyzed against phosphate-buffered saline (PBS) buffer prior to its use as immunogen (19). Goat (T1) and rabbit (C3) rCP antibodies were purified by ammonium sulfate precipitation and adjusted to $1.0 \mathrm{mg} / \mathrm{ml}$ (optical density at $280 \mathrm{~nm}\left[\mathrm{OD}_{280}\right]=1.45$ ) by spectrophotometry (11). The CCTEA detection protocol consists of whole-virus CTV polyclonal antibody provided by the University of California Citrus Clonal Protection Program (CCPP) (Department of Plant 
Table 1. Citrus tristeza virus (CTV) isolates from the international collection of the United States Department of Agriculture confined under quarantine conditions at Beltsville, MD (13) used to evaluate the reactivity of goat $\mathrm{T} 1$ and rabbit $\mathrm{C} 3$ recombinant coat protein antibodies

\begin{tabular}{|c|c|c|c|}
\hline Sample no. & CTV isolate & Origin & Biological properties $^{\mathrm{a}}$ \\
\hline 1 & B-002 & United States & Mild \\
\hline 2 & B-006 & United States & DC,SY,GSP,OSP \\
\hline 3 & B-007 & South Africa & GSP \\
\hline 4 & B-007-1 & South Africa & GSP \\
\hline 5 & B-012 & Brazil & DC,SY,OSP \\
\hline 6 & B-012-1 & Brazil & DC,SY \\
\hline 7 & B-014 & Brazil & DC,SY,OSP \\
\hline 8 & B-014-4 & Brazil & DC,SY \\
\hline 9 & B-014-6 & Brazil & DC,SY,GSP,OSP \\
\hline 10 & B-016 & Brazil & DC,SY \\
\hline 11 & B-017 & Brazil & DC,SY,GSP,OSP \\
\hline 12 & B-017-3 & Brazil & DC,SY,OSP \\
\hline 13 & B- 023 & Israel & GSP \\
\hline 14 & B-023-9 & Israel & DC,GSP \\
\hline 15 & B-028 & United States & DC,SY,GSP,OSP \\
\hline 16 & B-030 R1 & Japan & DC,SY,OSP \\
\hline 17 & B-030-1 & Japan & DC \\
\hline 18 & B- $030-2$ & Japan & DC,GSP \\
\hline 19 & B-030-2-1 & Japan & DC \\
\hline 20 & B-030-4 & Japan & DC,SY,GSP,OSP \\
\hline 21 & B-031 & Japan & GSP,OSP \\
\hline 22 & B-031-2 & Japan & SY,GSP,OSP \\
\hline 23 & B-035 & Spain & Mild \\
\hline 24 & B-046 & South Africa & DC,GSP \\
\hline 25 & B-063 & China & DC,SY,GSP,OSP \\
\hline 26 & B-065 & China & DC,SY,GSP,OSP \\
\hline 27 & B-065-1 & China & DC,SY,GSP,OSP \\
\hline 28 & B- $065-2$ & China & DC,SY,GSP \\
\hline 29 & B-077 & Brazil & DC,SY,GSP,OSP \\
\hline 30 & B-077-1 & Brazil & $\mathrm{DC}$ \\
\hline 31 & B-083 & China & DC,GSP \\
\hline 32 & B-128 & Colombia & DC,SY,OSP \\
\hline 33 & B-134 & Peru & DC,SY,GSP \\
\hline 34 & B-135 & Peru & DC,SY,GSP,OSP \\
\hline 35 & B-144 & China & DC,SY,GSP \\
\hline 36 & B-181 & Costa Rica & Mild \\
\hline 37 & B-185 & Japan & DC,SY,GSP,OSP \\
\hline 38 & B-187 & Australia & DC,SY,GSP \\
\hline 39 & B-188 & Japan & GSP \\
\hline 40 & B-190 & Japan & Mild \\
\hline 41 & B-192 & France & Mild \\
\hline 42 & B-194 & India & DC,SY, OSP \\
\hline 43 & B-195 & India & DC,SY,GSP,OSP \\
\hline 44 & B-198 & Israel & DC,GSP \\
\hline 45 & B-198-1 & Israel & GSP \\
\hline 46 & B-199 & Israel & DC,SY,GSP,OSP \\
\hline 47 & B-199-1 & Israel & DC,SY,OSP \\
\hline 48 & B-211 & Taiwan & DC,SY,GSP \\
\hline 49 & B-215 & Japan & Mild \\
\hline 50 & B-222 & India & $\mathrm{DC}, \mathrm{SY}$ \\
\hline 51 & B-227 & India & DC,SY,GSP,OSP \\
\hline 52 & B-252 & Taiwan & $\mathrm{DC}$ \\
\hline 53 & B-256 & Indonesia & DC,SY,GSP,OSP \\
\hline 54 & B-270 & China & DC,SY,GSP,OSP \\
\hline 55 & B-276 & Costa Rica & Mild \\
\hline 56 & B-280 & Taiwan & DC,GSP \\
\hline 57 & B-296 & Dominican Republic & $\mathrm{DC}$ \\
\hline 58 & B-297 & Dominican Republic & DC,GSP \\
\hline 59 & B-300 & Puerto Rico & DC,GSP \\
\hline 60 & B-305 & Cuba & Mild \\
\hline 61 & B-310 & Cuba & DC,GSP \\
\hline 62 & B-316 & Taiwan & DC,SY,GSP,OSP \\
\hline 63 & B-318 & Taiwan & Mild \\
\hline 64 & B-335 & United States & DC,GSP \\
\hline 65 & B-352 & United States & DC,SY,GSP \\
\hline 66 & B-365 & Spain & DC \\
\hline 67 & B-370 & Australia & DC,SY,GSP,OSP \\
\hline 68 & B-372 & Australia & DC,SY,GSP,OSP \\
\hline 69 & B-373 & Australia & DC,SY,GSP,OSP \\
\hline
\end{tabular}

${ }^{\mathrm{a}}$ Mild $=$ mild in sweet orange on sour orange combination, $\mathrm{DC}=$ decline in sweet orange on sour orange combination, $\mathrm{SY}=$ seedling yellows on sour orange, GSP $=$ stem pitting on Duncan grapefruit, and OSP = stem pitting on Madam vinous sweet orange.
Pathology, University of California, Riverside) and rabbit polyclonal antibody developed to a maltose-binding recombinant $\mathrm{CP}$ of California SY568 CTV isolate (25). The third source of CTV antibodies was that of Agdia SRA 78900/1000 (Elkhart, IN).

Tissue samples. Citrus tissue analyzed in this study were from three sources. (i) Citrus samples from the international collection of CTV isolates of the United States Department of Agriculture (USDA) located at Beltsville, MD (13). These CTV isolates represent the main groups of biologically characterized CTV strains from diverse geographic origins (Table 1). (ii) Citrus tissue from a collection of CTV isolates from California maintained under greenhouse conditions at the CCTEA at Tulare, CA (http://www.cctea.org/web\%20 page\%20averaged\%20rev.pdf). These CTV isolates represent all the groups of biologically characterized CTV strains from California. (iii) Citrus samples collected in commercial groves as part of the CCTEA's regular monitoring program in the San Joaquin Central Valley.

Tissue collection and sample preparation. Young, tender bark tissue was collected from the in planta CTV cultures maintained in quarantine in the USDA international collection of CTV isolates. The chopped bark tissue was homogenized using a Kleco tissue homogenizer (Garcia Machines, Visalia, CA) in extraction buffer (PBS; $8 \mathrm{mM} \mathrm{Na}_{2} \mathrm{HPO}_{4}, 14 \mathrm{mM} \mathrm{KH} \mathrm{KO}_{4}$, $15 \mathrm{mM} \mathrm{NaCl}$, pH 7.4 containing $0.05 \%$ Tween $20,2 \%$ polyvinylpyrrolidone [Sigma PVP 40; Sigma-Aldrich, St. Louis], and $0.2 \%$ bovine serum albumin) at a ratio of $1 / 10$ (grams fresh weight/volume). Following homogenization, the samples were aliquoted into glass vials and lyophilized. The lyophilized samples were stored at $-20^{\circ} \mathrm{C}$ except while being shipped under quarantine permit. To prepare the samples for assay, distilled water was added to the lyophilized sample to bring the volume to the original measure. The California citrus tissue was collected under a standard methodology developed by the CCTEA (31). In all, 8 to 10 tender flushes with fully expanded leaves were collected from each citrus plant, placed in plastic bags, labeled, and brought to the laboratory in ice chests. Antigen samples were prepared by grinding $0.5 \mathrm{~g}$ of petiole tissue in $5 \mathrm{ml}$ of extraction buffer using a Kleco tissue homogenizer (Garcia Machines).

Serological tests. All serological tests were performed according to the standard DASI-ELISA (11). Unless otherwise stated, $100 \mu \mathrm{l}$ was used per well and three washings with PBS $+0.05 \%$ Tween 20 (PBS-Tween) were performed between steps. Polystyrene flat bottom Nunc Maxisorb microtiter plates (Rochester, NY) were coated with the corresponding trapping antibodies diluted in carbonate buffer $\left(0.015 \mathrm{M} \mathrm{NaHCO}_{3}, 0.03 \mathrm{M}\right.$ $\mathrm{NaCO}_{3}, \mathrm{pH}$ 9.6) and incubated for $6 \mathrm{~h}$ at $37^{\circ} \mathrm{C}$. Antigen samples were incubated for 
16 to $18 \mathrm{~h}$ at $5^{\circ} \mathrm{C}$; each of the intermediate antibodies were diluted in conjugate buffer (PBS-Tween-PVP $+0.2 \%$ bovine serum albumin [wt/vol) and incubated for $4 \mathrm{~h}$ at $37^{\circ} \mathrm{C}$. After washing, the corresponding alkaline phosphatase enzyme conjugates were diluted in conjugate buffer and incubated for $2 \mathrm{~h}$ at $37^{\circ} \mathrm{C}$. At the end of the incubations, the reaction with p-nitrophenyl phosphate (Sigma N 2765) at $1.0 \mathrm{mg} / \mathrm{ml}$ in $10 \%$ diethanolamine, $\mathrm{pH} 9.8$, was quantified after $1 \mathrm{~h}$ at $405 \mathrm{~nm}\left(\mathrm{OD}_{405}\right)$ using an ELISA plate reader. Goat $\mathrm{T} 1$ trapping and rabbit $\mathrm{C} 3$ intermediate $\mathrm{rCP}$ antibodies were used at 3 and $0.1 \mu \mathrm{g} / \mathrm{ml}$, respectively; goat anti-rabbit immunoglobulin $\mathrm{G}$ alkaline phosphatase conjugate (Sigma A3812) was used at 1:30,000 dilution. CCTEA antibodies were used according to a preestablished protocol
(31) and Agdia's detection kit was used as recommended by the supplier. In each experiment, CTV antigens included two replications of each citrus sample. Standards of CTV-infected citrus tissue and extracts of sweet orange, grapefruit, and mandarin $(C$. recticulata Blanco) of healthy greenhousegrown plants were included as positive and the negative controls, respectively. When $\mathrm{OD}_{405}$ readings were greater than two times the mean of the healthy controls, reactions were considered positive (+). Reactions with $\mathrm{OD}_{405}$ values less than 0.100 or two times the mean of the healthy controls were considered negative (-). The threshold for negative and positive reactions was only an estimated value and has been routinely used at the CCTEA in the annual regular monitoring program.

\section{RESULTS}

Reactivity of goat T1 and $\mathrm{C} 3$ rCP antibodies to a collection of CTV isolates from diverse geographic origins. This part of the work was conducted at the USDA National Clonal Germplasm Repository for Citrus and Dates located at Riverside, CA. Using goat $\mathrm{T} 1$ and rabbit $\mathrm{C} 3 \mathrm{rCP}$ antibodies to test all the CTV isolates, $\mathrm{OD}_{405}$ values between 0.250 and 2.200 were observed (Fig. 1). In all, 6 $(8.69 \%)$ CTV isolates gave $\mathrm{OD}_{405}$ readings between 0.200 and $0.500,9(13.04 \%)$ between 0.500 and $1.000,30(43.47 \%)$ between 1.000 and $1.500,20(28.98 \%)$ between 1.500 and 2.000 , and $4(5.79 \%)$ higher than 2.000. Conversely, $\mathrm{OD}_{405}$ values for healthy tissue samples were lower than 0.100 (Fig. 1).

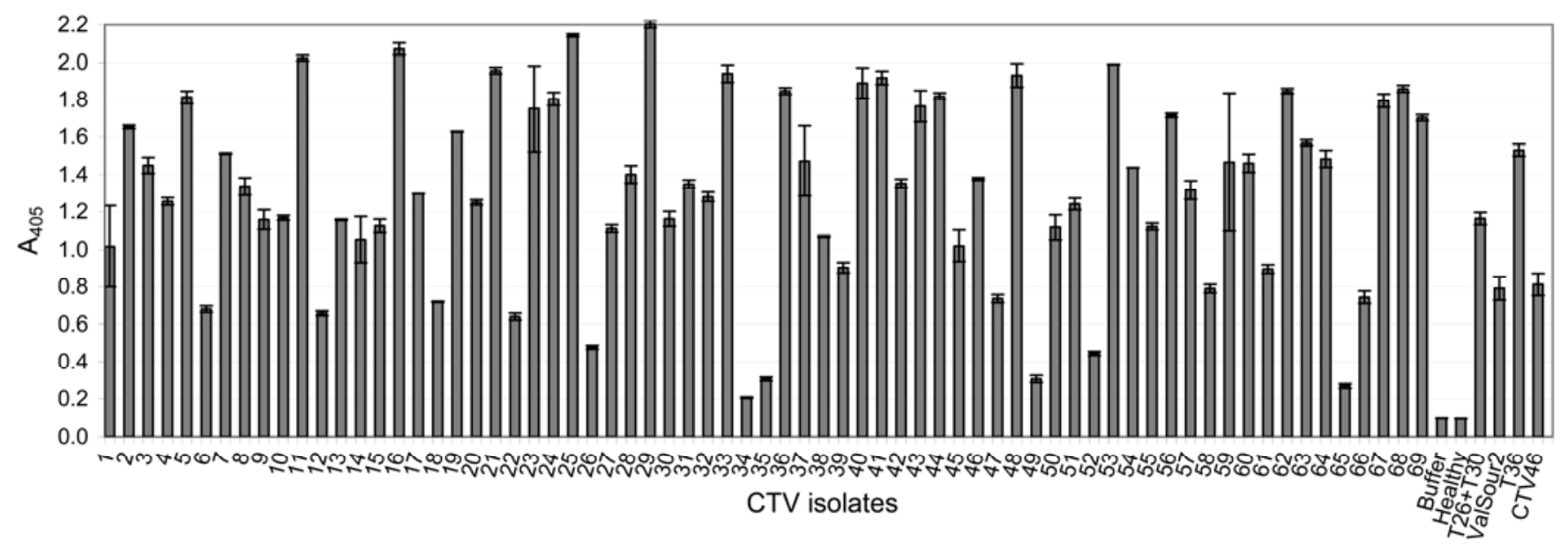

Fig. 1. Detection of Citrus tristeza virus (CTV) with T1 and C3 recombinant coat protein antibodies from the international collection of the United States Department of Agriculture confined under quarantine conditions at Beltsville, MD from diverse geographical origins. The upper bar of every optical density at $405 \mathrm{~nm}\left(\mathrm{~A}_{405}\right)$ reading indicates the standard deviation for two replications per CTV isolate. Healthy = tissue of Madam Vinous sweet orange grown plants. Positive controls were citrus tissue infected with CTV isolates T26/T30, Valencia/Sour 2, T36, and T46. One plant was used per each CTV isolate. See Table 1 and Materials and Methods for details.

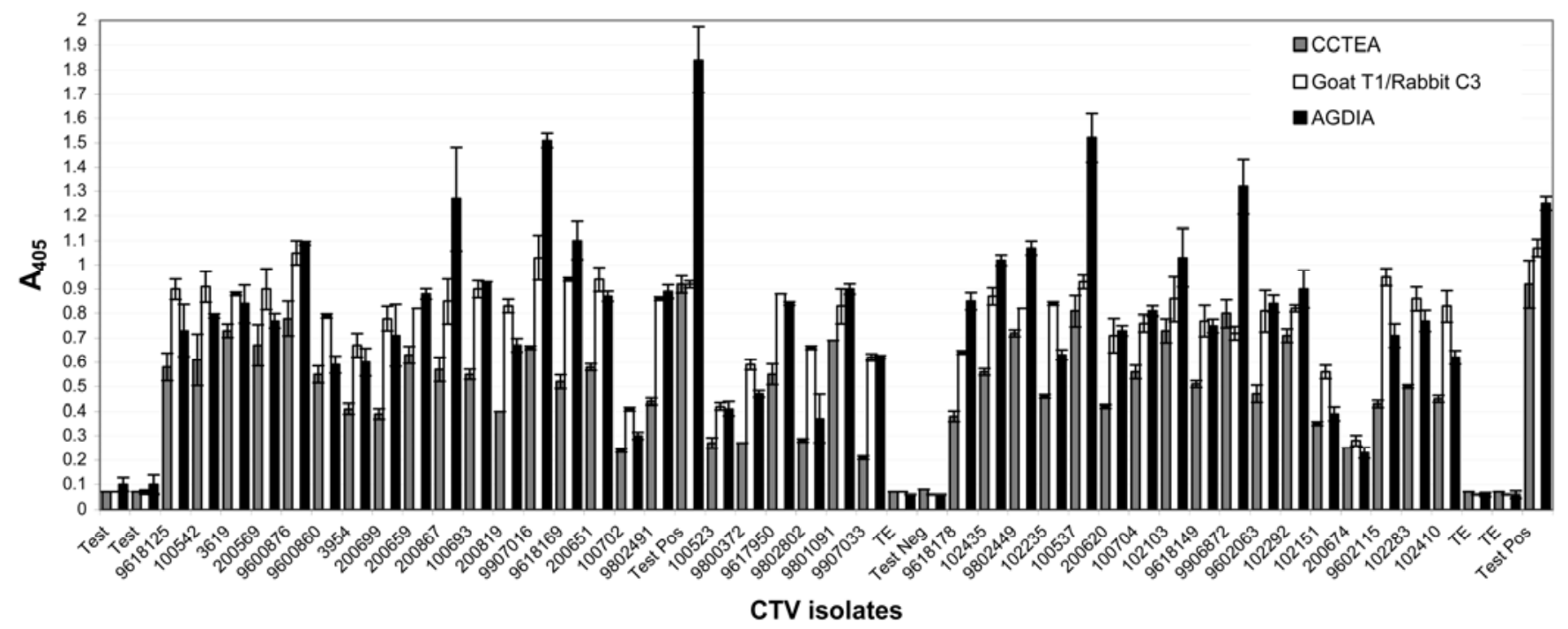

Fig. 2. Comparison of enzyme-linked immunosorbent assay results using goat $\mathrm{T} 1$ and rabbit $\mathrm{C} 3$ recombinant coat protein antibodies with Central California Tristeza Eradication Agency (CCTEA) antibodies, and a commercial detection kit from Agdia for the detection of Citrus tristeza virus (CTV) from 40 California CTV isolates. The upper bar of every optical density at $405 \mathrm{~nm}\left(\mathrm{~A}_{405}\right)$ reading indicates the standard deviation for two replications per CTV isolate. Test and TE $=$ extraction buffer; Test Pos = positive control; Test Neg = negative control. Negative control consisted of a mix of tissue of Washington Navel and Valencia oranges, Murcott mandarin, Mexican Lime, and S-1 citron. Positive control consisted of tissue of Madam Vinous sweet orange samples infected with California CTV isolates numbers 107, 99402, and 575 (http://www.cctea.org/web\%20page\%20averaged\%20rev.pdf). See Materials and Methods for details. 
Comparison of goat $\mathrm{T} 1$ and $\mathrm{C3}$ rCP antibodies with the CCTEA protocol and a commercial CTV detection kit. The combination of goat $\mathrm{T} 1$ and rabbit $\mathrm{C} 3$ rCP antibodies was further evaluated in DASI-ELISA tests at the CCTEA facilities located at Tulare, CA, using a collection of 280 California CTV isolates maintained under greenhouse conditions. In the first test, the $\mathrm{OD}_{405}$ readings of $40 \mathrm{CTV}$ isolates were used to compare the $\mathrm{T} 1$ and $\mathrm{C} 3$ antibodies with the CCTEA antibodies and a commercial kit available from Agdia (Fig. 2). Each antibody source consistently distinguished the CTV-positive and -negative samples with $\mathrm{OD}_{405}$ values between 0.250 and 1.850 for CTV-infected tissue, whereas $\mathrm{OD}_{405}$ values for healthy tissue samples were less than 0.100 for all three antibody sources (Fig. 2). In addition, the CTV-positive and -negative samples were properly discriminated using any of the three CTV detection DASI-ELISA protocols (Fig. 2). In a second test, 240 additional California CTV isolates from the collection were evaluated in a comparable DASI-ELISA test by using the goat T1 and rabbit $\mathrm{C} 3 \mathrm{rCP}$ antibodies and the CCTEA protocol. Again, for both DASI-ELISA protocols, there was a $100 \%$ concurrence of discriminating between CTV-positive and -negative samples (Table 2). Comparing the two DASI-ELISA protocols, 152 CTV isolates $\left(63.33 \%\right.$ ) gave equal $\mathrm{OD}_{405}$ values (less than 0.100 difference) for both protocols, $67(27.91 \%)$ gave $\mathrm{OD}_{405}$ values higher than 0.100 by the CCTEA protocol than the combination of goat T1 and rabbit $\mathrm{C} 3$ antibodies, and $21(8.75 \%)$ gave $\mathrm{OD}_{405}$ values higher than 0.100 by goat $\mathrm{T} 1$ and rabbit $\mathrm{C} 3$ than the CCTEA protocol (Table 2).

Evaluation of goat T1 and $\mathrm{C3}$ rCP antibodies with field-collected samples. The combination of goat $\mathrm{T} 1$ and rabbit $\mathrm{C} 3$ rCP antibodies was evaluated in DASIELISA tests for its suitability for largescale field indexing. In the first test, we evaluated five blocks planted with diverse mandarin cultivars with previous observations of atypically high $\mathrm{OD}_{405}$ readings with DASI-ELISA during the spring of the regular monitoring program by the CCTEA $(30,41)$. With the CCTEA proto-

Table 2. Comparison of goat $\mathrm{T} 1$ and rabbit $\mathrm{C} 3$ recombinant coat protein antibodies with the Central California Tristeza Eradication Agency (CCTEA) protocol for the detection of Citrus tristeza virus (CTV) with 260 California CTV isolates ${ }^{\mathrm{a}}$

\begin{tabular}{lcccc}
\hline & \multicolumn{4}{c}{ No. of samples (\%) } \\
\cline { 2 - 5 } CTV isolates & $\begin{array}{c}\text { Equal OD }_{\text {405 }} \\
\text { between CCTEA } \\
\text { versus T1 and C3 }^{\mathbf{b}}\end{array}$ & $\begin{array}{c}\text { OD values }>\mathbf{0 . 1 0 0} \\
\text { by CCTEA than by } \\
\text { T1 and C3 }\end{array}$ & $\begin{array}{c}\text { OD values }>\mathbf{0 . 1 0 0} \\
\text { by T1 and C3 than } \\
\text { by CCTEA }\end{array}$ & Total \\
\hline $41-88$ & $18(37.50)$ & $23(48.00)$ & $7(14.58)$ & $48(100)$ \\
$89-136$ & $33(68.75)$ & $10(20.83)$ & $5(10.41)$ & $48(100)$ \\
$137-184$ & $34(70.84)$ & $9(18.75)$ & $5(10.41)$ & $48(100)$ \\
$185-232$ & $37(77.08)$ & $7(14.58)$ & $4(8.33)$ & $48(100)$ \\
$233-280$ & $30(62.50)$ & $18(37.50)$ & $0(0 \%)$ & $48(100)$ \\
Total & 152 & 67 & 21 & $240(100)$ \\
\hline
\end{tabular}

a See Materials and Methods for details.

${ }^{\text {b }}$ Equal optical density at $405 \mathrm{~nm}\left(\mathrm{OD}_{405}\right)$ values $\left(<0.100\right.$ difference); $\mathrm{OD}_{405}$ readings were $\leq 0.100$ different among them. col, the $\mathrm{OD}_{405}$ readings of 428 field-grown mandarin samples were in the range of 0.083 to 0.213 (Table 3 ). In contrast, the $\mathrm{OD}_{405}$ readings of the same 428 mandarin samples analyzed with the combination of $\mathrm{T} 1$ and $\mathrm{C} 3 \mathrm{rCP}$ antibodies were in the range of 0.056 to 0.097 . In both assays, the mean $\mathrm{OD}_{405}$ readings for healthy negative controls were consistently lower than 0.100. Likewise, CTV-infected positive controls ranged from 1.177 to 1.337 for the CCTEA protocol and 1.008 to 1.273 for the $\mathrm{T} 1$ and $\mathrm{C} 3 \mathrm{rCP}$ antibodies (Table 3). On the basis that reactions were considered positive (+) when the mean of $\mathrm{OD}_{405}$ values were greater than two times that of the mean of the healthy controls, there were zero CTV positives detected with the combination of $\mathrm{T} 1$ and $\mathrm{C} 3 \mathrm{rCP}$ antibodies, whereas the CCTEA protocol resulted in 45 potentially CTV-positive samples in these four mandarin blocks (Table 3 ). In a separate study (41), samples from these suspect CTV-positive mandarin samples were proven to be CTV negative by immunocapture reverse-transcription polymerase chain reaction (IC-RT-PCR); hence, we concluded that they were false positives. We also evaluated the combination of $\mathrm{T} 1$ and $\mathrm{C} 3 \mathrm{rCP}$ antibodies with samples collected in commercial groves as part of the CCTEA's regular monitoring program. The evaluation included 41,195 samples from 301 commercial groves from districts 1, 2, and 3 of the California Central Valley. In total, 26 trees were found to be CTV positive, with the $\mathrm{T} 1$ and $\mathrm{C} 3 \mathrm{rCP}$ antibody combination resulting in $0.063 \%$ of CTV infected samples (Table 4).

\section{DISCUSSION}

In this work, we report the advantages of using of goat $\mathrm{T} 1$ as the capture (trapping) and rabbit $\mathrm{C} 3$ as the intermediate (detecting) rCP antibodies as a DASI-

Table 3. Serological comparison of the Central California Tristeza Eradication Agency (CCTEA) protocol and T1 and C3 recombinant coat protein antibodies with field-collected mandarin samples and known positive and negative Citrus tristeza virus (CTV)-infected controls in double-antibody sandwich indirect enzyme-linked immunosorbent assay (DASI ELISA) ${ }^{\mathrm{a}}$

\begin{tabular}{|c|c|c|c|c|c|c|c|}
\hline Block & Cultivar & $\begin{array}{c}\text { Total } \\
\text { samples }\end{array}$ & $\begin{array}{c}\text { Mean } \\
\text { OD }_{405}{ }^{b}\end{array}$ & $\begin{array}{l}\text { Range } \\
\text { OD }_{405}\end{array}$ & $\begin{array}{l}\text { No. of positive } \\
\text { samples }^{c}\end{array}$ & $\begin{array}{c}\text { Healthy control } \\
\text { OD }_{405}\end{array}$ & $\begin{array}{c}\text { Positive control } \\
\text { OD }_{405}\end{array}$ \\
\hline \multicolumn{8}{|c|}{ CCTEA protocol } \\
\hline $45 \mathrm{~A}$ & Unknown mandarin & 144 & 0.139 & $0.207-0.101$ & 20 & 0.083 & 1.337 \\
\hline 04B & Unknown young citrus & 93 & 0.117 & $0.183-0.079$ & 19 & 0.079 & 1.177 \\
\hline $06^{\mathrm{a}}$ & Unknown young citrus & 117 & 0.112 & $0.213-0.078$ & 19 & 0.079 & 1.216 \\
\hline $04 \mathrm{~F}$ & Unknown mandarin & 42 & 0.120 & $0.182-0.087$ & 3 & 0.083 & 1.323 \\
\hline $04 \mathrm{G}$ & Unknown mandarin & 42 & 0.121 & $0.163-0.083$ & 4 & 0.074 & 1.206 \\
\hline Total & $\ldots$ & 428 & $\ldots$ & $\ldots$ & 45 & $\ldots$ & $\ldots$ \\
\hline \multicolumn{8}{|c|}{$\mathrm{T} 1$ and $\mathrm{C} 3$ antibodies } \\
\hline $45 \mathrm{~A}$ & Unknown mandarin & 144 & 0.065 & $0.097-0.061$ & 0 & 0.064 & 1.273 \\
\hline 04B & Unknown young citrus & 93 & 0.061 & $0.065-0.060$ & 0 & 0.059 & 1.175 \\
\hline $06^{\mathrm{a}}$ & Unknown young citrus & 117 & 0.062 & $0.074-0.057$ & 0 & 0.060 & 1.166 \\
\hline $04 \mathrm{~F}$ & Unknown mandarin & 42 & 0.057 & $0.070-0.053$ & 0 & 0.053 & 1.008 \\
\hline $04 \mathrm{G}$ & Unknown mandarin & 42 & 0.061 & $0.070-0.056$ & 0 & 0.060 & 1.044 \\
\hline Total & $\ldots$ & 428 & $\ldots$ & $\ldots$ & 0 & $\ldots$ & $\ldots$ \\
\hline
\end{tabular}

${ }^{a}$ See Materials and Methods for details.

${ }^{b}$ Optical density at $405 \mathrm{~nm}\left(\mathrm{OD}_{405}\right)$ after $60 \mathrm{~min}$ of substrate reaction. Mean of two replications per ELISA plate. Reactions were considered positive (+) when the mean of $\mathrm{OD}_{405}$ was higher than two times the mean of healthy controls or 0.100 , whichever was greater. Reactions with lower values were considered negatives (-).

c The number of "positive samples" with the CCTEA protocol are, in fact, false positives. 
ELISA complete CTV kit. The detection of CTV antigens was consistent and the discrimination of healthy tissue samples from samples of diverse citrus plants was more than satisfactory. Goat $\mathrm{T} 1$ and rabbit $\mathrm{C} 3$ rCP antibodies showed $100 \%$ virus detection (Fig. 1) with a collection of $69 \mathrm{CTV}$ isolates that cause a broad spectrum of disease symptoms in different citrus hosts, such as decline, seedling yellows, orange stem pitting, grapefruit stem pitting, or mild symptoms, as well as combinations of these symptoms. Likewise, these CTV isolates represent virus populations from 18 countries on five continents. $\mathrm{OD}_{405}$ readings in the range of 0.500 to 2.200 were consistent in $93 \%$ of the CTV iso$\mathrm{OD}_{405}$ in the range of 0.200 and 0.500 , which was considered still adequate for virus detection when the $\mathrm{OD}_{405}$ values for the healthy controls were less than 0.100 (Fig. 1). The differences in $\mathrm{OD}_{405}$ readings showed by all CTV isolates from the international USDA collection must have been related to differences in virus titer in the test plants rather than differential specificity to the rCP antibodies. C3 rCP antibodies also showed $100 \%$ virus detection with the 280 CTV isolates from California (Fig 2; Table 2). These CTV isolates also exhibited a wide range of CTV symptoms in different citrus hosts and are representative of the CTV isolates that have been found in California citrus groves since 1993 (29). The results obtained with goat $\mathrm{T} 1$ and rabbit $\mathrm{C} 3 \mathrm{rCP}$ antibodies with the California CTV isolates were comparable with the level of detection achieved with the CCTEA's protocol and Agdia's detection kit, respectively, with $100 \%$ detection of CTV by the three sources of antibodies. There were some slight differences in the $\mathrm{OD}_{405}$ values obtained by goat $\mathrm{T} 1$ and rabbit $\mathrm{C} 3 \mathrm{rCP}$ antibodies compared with the CCTEA's protocol and Agdia's detection kit (Fig 2; Table 2); however, these differences were similar to those that are normally found when several commercially available serological kits are compared for CTV detection (21) and can be explained on the basis of the nature of the source of antisera (21), where a combination of antibody concentration and specificity must be involved.

In addition, goat $\mathrm{T} 1$ and rabbit $\mathrm{C} 3 \mathrm{rCP}$ antibodies were useful for large-scale inlates tested; only six CTV isolates gave

The combination of goat $\mathrm{T} 1$ and rabbit

dexing of citrus trees (Tables 3 and 4), even with field-grown mandarin cultivars exhibiting atypically high $\mathrm{OD}_{405}$ values in DASI-ELISA tests performed with the CCTEA's protocol $(30,41)$. The $\mathrm{OD}_{405}$ readings with field-grown mandarin samples evaluated were in the range of 0.083 to 0.213 with the CCTEA's antibodies, whereas the $\mathrm{OD}_{405}$ readings with the same mandarin samples analyzed with the $\mathrm{T} 1$ and $\mathrm{C} 3 \mathrm{rCP}$ antibodies were in the range of 0.056 to 0.097 (Table 3 ). The reason why this phenomenon occurred with the CCTEA's protocol and not with the T1 and $\mathrm{C} 3 \mathrm{rCP}$ antibodies is unknown. It has been hypothesized that a stress-related protein present in field-grown mandarin cultivars under some adverse environmental conditions is involved in the atypically high $\mathrm{OD}_{405}$ readings in DASI-ELISA tests (30). However, this hypothesis warrants further verification.

CTV is a quarantine pathogen in many countries and several million trees are analyzed every year worldwide to detect the presence of CTV to prevent further spread of the virus, either from valuable, commercial budwood sources registered though certification programs or natural spread in the field. Results of this work provide evidence that antibodies developed against the $\mathrm{rCP}$ of CTV are a viable option for large-scale indexing of citrus trees. According to our system, the key points are to have the cultures of E. coli transformed with the p25 CP gene of CTV, then to purify the corresponding untagged recombinant $\mathrm{CP}$ through SDS-PAGE followed by extensive dialysis to eliminate SDS from the gel slices containing the rCP prior its use as an immunogen, and to have a reliable system for the massive production and evaluation of the CTV-specific antisera. These features may guarantee a permanent supply of CTV antibodies to support the continuous activities of any large CTV-monitoring program worldwide. Currently, several serological detection kits are commercially available for CTV, mostly from the United States, Spain, Switzerland, and Italy. Although these serological kits are efficient for CTV detection, they are relatively expensive and their costs significantly increase when they have to be imported into other countries. Additionally, their availability is not always immediate (21); these features, consequently, limit their usefulness for large-

Table 4. Detection of Citrus tristeza virus (CTV) with $\mathrm{T} 1$ and $\mathrm{C} 3$ recombinant coat protein antibodies from field samples of young plantings $(<5$ years) of sweet orange and mandarin cultivars collected from March to June 2007 in three pest control districts in three counties of California's Central San Joaquin Valley

\begin{tabular}{lcccc}
\hline District & $\begin{array}{c}\text { No. of groves } \\
\text { monitored for CTV }\end{array}$ & $\begin{array}{c}\text { No. of samples } \\
\text { monitored for CTV }\end{array}$ & $\begin{array}{c}\text { No. of samples } \\
\text { positive for CTV }\end{array}$ & $\begin{array}{c}\text { CTV detected } \\
\text { samples (\%) }\end{array}$ \\
\hline No. 1 & 54 & 5,268 & 0 & 0.000 \\
No. 2 & 233 & 34,559 & 15 & 0.043 \\
No. 3 & 14 & 1,368 & 11 & 0.804 \\
Total & 301 & 41,195 & 26 & 0.063 \\
\hline
\end{tabular}

scale indexing, especially for those citrus industries where the serological detection kits must be imported from foreign sources.

\section{ACKNOWLEDGMENTS}

This research was supported by CONACYT projects 03295 , 53074/2006, and PAICYTdUANL project CN 311-00 from Mexico. We thank J. V. da Graça and V. J. Febres for critically reviewing the manuscript; and C. Wallen, T. Patiño, and P. Ballance for their invaluable expertise.

\section{LITERATURE CITED}

1. Bar-Joseph, M., Filatov, V., Gofman, R. Guang, Y., Hadjinicolism A., Mawassi, M., Gootwine, E., Weisman, Y., and Malkinson, M. 1997. Booster immunization with partially purified citrus tristeza virus (CTV) preparation after priming with recombinant CTV coat protein enhances the binding capacity of capture antibodies by ELISA. J. Virol. Methods 67:1922.

2. Bar-Joseph, M., Garnsey, S. M., Gonsalves, D., Moscovitz, M., Purciful, D. E., Clark, M. F., and Loebenstein, G. 1979. The use of enzyme-linked immunosorbent assay for the detection of citrus tristeza virus. Phytopathology 69:190-194.

3. Bar-Joseph, M., and Lee, R. F. 1989. Citrus tristeza virus. Descriptions of Plant Viruses No. 353 (No. 33 revised). Commonwealth Mycological Institute, Kew, Surrey, UK.

4. Bar-Joseph, M., and Malkinson, M. 1980. Hen yolk as a source of antiviral antibodies in the enzyme-linked immunosorbent assay (ELISA): a comparison of two plant viruses. J. Virol. .Methods 1:1-5.

5. Bar-Joseph, M., Marcus, R., and Lee, R. F. 1989. The continuous challenge of citrus tristeza virus control. Annu. Rev. Phytopathol. 27:292-316.

6. Batista, L. 2001. Obtención y evaluación de un anticuerpo monoclonal para la detección del virus de la tristeza de los cítricos: Aplicación en estudios epifitiológicos. Ph.D. thesis, Universidad Central de Las Villas, Cuba.

7. Batista, L., Peña, I., López, D., Casín, J. C., Velásquez, K., Torres, M. C., and León, Y. 2005. Management program for citrus tristeza in Cuba. Pages 404-406 in: Proc. 16th Conf Int. Org. Citrus Virol. M. E. Hilf, N. DuránVila, and M. A. Rocha-Peña, eds. IOCV, Riverside, CA.

8. Cambra, M., Camarasa, E., Gorris, M. T., Garnsey, S. M., and Carbonell, E. 1991. Comparison of different immunosorbent assays for citrus tristeza virus (CTV) using CTV specific monoclonal and polyclonal antibodies. Pages 38-45 in: Proc. 11th Conf. Int. Organ. Citrus Virol. R. H. Brlansky, R. F. Lee, and L. W. Timmer, eds. IOCV, Riverside, CA.

9. Cambra, M., Gorris, M. T., Marroquín, M. Román, M. P., Olmos, A., Martínez, M, C., Hermoso de Mendoza, A., López, A., and Navarro, L. 2000. Incidence and epidemiology of citrus tristeza virus in the Valencian community of Spain. Virus Res. 71:85-95.

10. Clark, M. F., and Adams, A. M. 1977. Characteristics of the microplate method of enzyme-linked immunosorbent assay for the detection of plant viruses. J. Gen. Virol. 34:475-483.

11. Clark, M. F., Lister, R. M., and Bar-Joseph, M. 1986. ELISA techniques. Methods Enzymol 113:742-766.

12. Garnsey, S. M., Bar-Joseph, M., and Lee, R. F. 1981. Applications of serological indexing to develop control strategies for citrus tristeza virus. Proc. Int. Soc. Citric. 1:448-452.

13. Garnsey, S. M., Civerolo, E. L., Gumpf, D. J., Paul, C., Hilf, M. E., Lee, R. F., Brlansky, R. H., Yokomi, R. K., and Hartung, J. S. 2005. Biological characterization of an international collection of Citrus tristeza virus (CTV) iso- 
lates. Pages 75-93 in: Proc. 16th Conf. Int. Organ. Citrus Virol. M. E. Hilf, N. Durán-Vila, and M. A. Rocha-Peña, eds. IOCV, Riverside, CA.

14. Garnsey, S. M., Gottwald, T. R., and Borbon, J. C. 1996. Rapid dissemination of mild isolates of Citrus tristeza virus following the introduction of Toxoptera citricida in the Dominican Republic. Pages 92-103 in: Proc. 13th Conf. Int. Organ. Citrus Virol. J. V. da Graça, P. Moreno, and R. K. Yokomi, eds. IOCV, Riverside, CA.

15. Garnsey, S. M., Permar, T. A., Cambra, M., and Henderson, C. T. 1993. Direct tissue blot immunoassay (DTBIA) for detection of citrus tristeza virus (CTV). Pages 39-50 in: Proc. 12th Conf. Int. Organ. Citrus Virol. P. Moreno, J. V. da Graça, and L. W. Timmer, eds. IOCV, Riverside, CA.

16. Gonsalves, D., Purcifull, D. E., and Garnsey, S. M. 1978. Purification and serology of citrus tristeza virus. Phytopathology 68:553-559.

17. Gottwald, T. R., Cambra, M., and Moreno, P. 1993. The use of serological assays to monitor spatial and temporal spread of citrus tristeza virus in symptomless trees in Eastern Spain. Pages 51-61 in: Proc. 12th Conf. Int. Organ. Citrus Virol. P. Moreno, J. V. da Graça, and L. W. Timmer, eds. IOCV, Riverside, CA.

18. Gottwald, T. R., Polek, M., and Riley, K. 2002. History, present incidence, and spatial distribution of Citrus tristeza virus in the California Central Valley. Pages 83-94 in: Proc. 15th Conf. Int. Organ. Citrus Virol. N. Durán-Vila, R. G. Milne, and J. V. da Graça, eds. IOCV, Riverside, CA.

19. Iracheta-Cárdenas, M., Sandoval-Alejos, B. D., Román-Calderón, M. E., Manjunath, K. L., Lee, R. F., and Rocha-Peña, M. A. 2008. Production of polyclonal antibodies to the recombinant coat protein of Citrus tristeza virus and their effectiveness for virus detection. J. Phytopathol. 156:243-250.

20. Iracheta-Cárdenas, M. M., Almeyda-León, I. H., Manjunath, K. L. Cevik, B., Nibblett, C., Lee, R., and Rocha-Peña, M. A. 2002. Molecular cloning and expression of the p25 gene of two Mexican isolates of Citrus tristeza virus. Rev. Mex. Fitopatol. 20:174-181.

21. Iracheta-Cárdenas, M. M., Peña, del Río. M. A., and Rocha-Peña, M. A. 2005. Comparación de antisueros comerciales para la detección del virus tristeza de los cítricos. Rev. Mex. Fitopatol. 23:323-328.

22. Lee, R. F., McConnell, P., Manjunath, K. L., Cevik, B., Nikolaeva, O. V., Dekkers, M. G. H., and Niblett, C. L. 2002. The Citrus tristeza virus epidemic in Bog Walk Valley, Jamaica. Pages 95-101 in: Proc. 15th Conf. Int. Organ.
Citrus Virol. N. Durán-Vila, N., R. G. Milne, and J. V da Graça, eds. IOCV, Riverside, CA.

23. Manjunath, K. L., Pappu, H. R., Lee, R. F., Niblett, C. L., and Civerolo, E. L. 1993. Studies on the coat protein genes of four isolates of citrus tristeza closterovirus from India: cloning, sequencing and expression. Pages 20-27 in: Proc. 12th Conf. Int. Organ. Citrus Virol. P. Moreno, J. V. da Graça, and L. W. Timmer, eds. IOCV, Riverside, CA.

24. Müller, G. W., and Garnsey, S. M. 1988. Efficiency of mechanical transmission of citrus tristeza virus. Pages 46-54 in: Proc. 10th Conf. Int. Organ. Citrus Virol. L. W. Timmer, S. M. Garnsey, and L. Navarro, eds. IOCV, Riverside, CA.

25. Nikolaeva, O. V., Karasev, A. V., Gumpf, D. J., Lee, R. F., and Garnsey, S. M. 1995. Production of polyclonal antisera to the coat protein of citrus tristeza virus expressed in Escherichia coli: application for immunodiagnosis. Phytopathology 85:691-694.

26. Nikolaeva, O. V., Karasev, A. V., Powell, C. A., Gumpf, D. J., Garnsey, S. M., and Lee, R. F. 1996. Mapping of epitopes for citrus tristeza virus specific monoclonal antibodies using bacterially expressed coat protein fragments. Phytopathology 86:974-979.

27. Permar, T. A., Garnsey, S. M., Gumpf, D. J., and Lee, R. F. 1990. A monoclonal antibody that discriminates strains of citrus tristeza virus. Phytopathology 80:224-228.

28. Polek, M. L. 2000. Permanent monitoring of Citrus tristeza virus and suppression of the disease by tree removal: the case of California. Hortic. Mex. 8:19-24

29. Polek, M., Gumpf, D. J., Wallen, C. M., and Riley, M. K. 2005. Biological characterization of naturally occurring Citrus tristeza virus strains in California citrus. Pages 68-74 in: Proc. 16th Conf. Int. Org. Citrus Virol. M. E. Hilf, N. Durán-Vila, and M. A. Rocha-Peña, eds. IOCV, Riverside, CA.

30. Polek, M., Metheney, P., and Wallen, C. 2004. Dubious optical density readings in ELISA testing for Citrus tristeza virus in mandarin varieties of citrus. (Abstr.) Phytopathology 94:S85.

31. Riley, K., and Polek, M. 2000. Central California Tristeza Eradication Agency: Lab procedures and quality assurance manual. Central California Tristeza Eradication Agency. Tulare.

32. Rocha-Peña, M. A., and Lee, R. F. 1991. Serological techniques for detection of citrus tristeza virus. J. Virol. Methods 34:311-331.

33. Rocha-Peña, M. A., Lee, R. F., Lastra R., Niblett, C. L., Ochoa-Corona, F. M., Garnsey, S. M., and Yokomi, R. Y. 1995. Citrus tristeza virus and its aphid vector Toxoptera citricida.
Threats to citrus production in Caribbean and Central and North America. Plant Dis. 79:437445.

34. Rocha-Peña, M. A., Lee, R. F., and Niblett, C. L. 1991. Development of a dot-immunobinding assay for citrus tristeza virus. J. Virol. Methods 34:297-309.

35. Rocha-Peña, M. A., Lee, R. F., and Niblett, C. L. 1993. Effectiveness of different citrus species as donor hosts for graft transmission of citrus tristeza virus. Pages 84-92 in: Proc. 12th Conf. Int. Organ. Citrus Virol. P. Moreno, J. V. da Graça, and L. W. Timmer, eds. IOCV, Riverside, CA.

36. Rocha-Peña, M. A., Lee, R. F., Permar, T. A., Yokomi, R. K., and Garnsey, S. M. 1991. Use of enzyme-linked immunosorbent and dotimmunobinding assays to evaluate two cross protection experiments after challenge with a severe citrus tristeza virus isolate. Pages 93102 in: Proc. 11th Conf. Int. Organ. Citrus Virol. R. H. Brlansky, R. F. Lee, and L. W. Timmer, eds. IOCV, Riverside, CA.

37. Rocha-Peña, M. A., Ochoa-Corona, F. M Martínez-Soriano, J. P., Roistacher, C. N., and Lee, R. F. 1998. Citrus tristeza virus: events that occur before, during and after the disease epidemics. Subtrop. Plant Sci. 50:26-36.

38. SAGARPA. 2004. Norma Oficial Mexicana NOM-031-FITO-2000, por la que se establece la campaña contra el virus tristeza de los cítricos. Secretaría de Agricultura, Ganadería Desarrollo Rural, Pesca y Alimentación. México.

39. Tragon, M. L. P. N., Nikolaeva, O., Manjunath, K. L., Lee, R. F., Muller, G. W., and Machado, M. A. 1997. Coat protein gene of a Brazilian isolate of the citrus tristeza virus: cloning, expression in E. coli and production of polyclonal antiserum. Fitopatol. Bras. 22:99-102.

40. Vela, C., Cambra, M., Cortés, E., Moreno, P., Miguel, J. G., Pérez de San Román, C., and Sanz, A. 1986. Production and characterization of monoclonal antibodies specific for citrus tristeza virus and their use in diagnosis. J. Gen. Virol. 67:91-96.

41. Yokomi, R. K., and Polek, M. L. 2007. Elevated background in DAS-I ELISA for the detection of Citrus tristeza virus in mandarin varieties. (Abstr.) Programme and Abstract Book, 17th Conf. Int. Organ. Citrus Virol. Adana, Turkey

42. Yokomi, R. K., Polek, M. L., Satar, S., and Gottwald, T. R. 2002. An economic sampling protocol for locating Citrus tristeza virus reservoirs in a large area. Pages 54-59 in: Proc. 15th Conf. Int. Organ. Citrus Virol. N. Durán Vila, R. G. Milne, and J. V. da Graça, eds IOCV, Riverside, CA 